\title{
Merkel Cell Carcinoma with Distant Metastasis to the Clivus Causing Symptoms Mimicking Tolosa-Hunt Syndrome: A Case Report and Literature Review
}

\author{
Kwo Wei David Ho', Peter A. Drew² and Miguel Chuquilin ${ }^{1 *}$ \\ 'Department of Neurology, University of Florida, Gainesville, FL, United States, ${ }^{2}$ Department of Pathology, University \\ of Florida, Gainesville, FL, United States
}

OPEN ACCESS

Edited by:

Daniel Monte Serrat Prevedello, The Ohio State University Columbus, United States

Reviewed by:

Alexandre Bossi Todeschini, The Ohio State University

Columbus, United States Andrew Scott Little, Barrow Neurological Institute, United States

Pierpaolo Peruzzi, Brigham and Women's Hospital, United States

*Correspondence: Miguel Chuquilin miguel.chuquilin@neurology.ufl.edu

Specialty section:

This article was submitted to Neuro-Oncology and Neurosurgical Oncology, a section of the journal Frontiers in Neurology

Received: 14 June 2017 Accepted: 28 July 2017 Published: 18 August 2017

Citation: Ho KWD, Drew PA and Chuquilin M (2017) Merkel Cell Carcinoma with Distant Metastasis to the Clivus Causing Symptoms Mimicking Tolosa-Hunt Syndrome: A Case Report and Literature Review.

Front. Neurol. 8:409.

doi: 10.3389/fneur.2017.00409
Merkel cell carcinoma (MCC) is an uncommon but highly malignant neuroendocrine tumor of the skin. MCC can metastasize, but involvement of the central nervous system is rare. Here, we report a case of rapidly progressing metastatic MCC to the clivus and bilateral cavernous sinus in an immunocompromised patient. This case is unique in that it is the first case report showing MCC metastasis to the clivus from a distant site. It also demonstrates that a MCC metastasis can masquerade with symptoms of Tolosa-Hunt syndrome. A literature review on MCC with CNS metastasis is presented.

Keywords: Merkel cell carcinoma, clivus, metastasis, Tolosa-Hunt syndrome, cranial nerve palsies, cavernous sinus

\section{INTRODUCTION}

A 60-year-old man presented to the emergency room with right eyelid ptosis, diplopia, and pain behind the right eye. Symptoms started 3 weeks ago with pain behind the right eye that was sharp and intermittent in nature, and each time lasting a few hours. He saw his ophthalmologist 1 week after symptom onset and was told to keep the eye moist with eye drops. However, the right retroocular pain gradually worsened and became $4 / 10$ in intensity. During this time, he also developed right-sided ptosis and diplopia with associated nausea and vomiting.

His medical history was significant for diabetes mellitus, end stage renal disease status post combined pancreatic and renal transplant 8 years ago (on tacrolimus, prednisone, and mycophenolate), coronary artery disease and left shoulder Merkel cell carcinoma (MCC) (T2 N1 M0 stage IIIB) with metastasis to the left axilla that was resected 4 months prior to his presentation. At the time of his initial diagnosis of MCC, patient refused chemotherapy because of the risk of transplant rejection and he only received local radiotherapy. In terms of surgical history, he had right cataract surgery 1 year ago.

His family history was significant for father with a stroke and mother with hypertension and renal disease. He never smoked and drank three glasses of wine per week. He did not use illicit drugs. He was a retired laboratory technician at a particle board plant. His home medications included amlodipine, aspirin, carvedilol, cholecalciferol, cyanocobalamin, doxazosin, magnesium oxide, mycophenolate, tacrolimus, albuterol, amoxicillin, atorvastatin, cetirizine, clonidine, clopidogrel, furosemide, levothyroxine, lisinopril, mometasone, multiple vitamin, prednisone, and ranitidine.

On physical exam, vital signs were $\mathrm{BP} 122 / 63$, pulse 65 , respiratory rate $14, \mathrm{SpO}_{2} 96 \%$.

There was complete right-sided ptosis (he was unable to open it), with complete right eye ophthalmoplegia. The right pupil was dilated, $7 \mathrm{~mm}$ in size and fixed. Shining light to the right pupil 
constricted the left pupil. Left pupil was $3 \mathrm{~mm}$ in size and reactive to light, but shining light into the left pupil did not constrict the right pupil. The left eye had complete abduction paralysis (Figure 1; Video S1 in Supplementary Material). Visual acuity was 20/40 OD, 20/20 OS. Intraocular pressures were normal. Proptosis was not present. Dilated fundus exam showed temporal pallor of the disk in the right eye, and slight pallor of the disk in the left eye. Pinprick was mildly impaired in the right V1 and left V3 distributions. The rest of the neurological exam was unremarkable.

Brain MRI with contrast 4 months prior to his presentation did not reveal any abnormality. Differential diagnosis on admission included multiple cranial neuropathies secondary to Tolosa-Hunt syndrome, cavernous sinus thrombosis, infection, granulomatous process or neoplasm, especially in the setting of MCC. Brain MRI showed infiltrative, peripherally enhancing tumor centered within the clivus with soft tissue extension into the cavernous sinus (Figure 2). Brain MRV was performed without contrast due to concern for his transplanted kidney function and the cavernous sinus was not well visualized. CT of the chest showed left axillary and left low cervical lymphadenopathy but negative for lung masses. He was started on Dexamethasone $4 \mathrm{mg}$ q6 hours to reduce tumor inflammation. Biopsy of the clival mass was performed with stereotactic, stealth CT-guided bilateral endoscopic sphenoidotomy and partial ethmoidectomy. The posterior vomer and intersinus septum were removed within the sphenoid and biopsies were taken from the sphenoid mass seen along the floor. H\&E slides of the biopsy showed a small round blue cell tumor. Immunuohistochemical slides showed the tumor was positive for CD56, cytokeratin CAM 5.2 (perinuclear dot-like pattern), and cytokeratin 20 (perinuclear dot-like pattern). The tumor was negative for TTF-1, leukocyte common antigen (LCA), S-100, and melan-A (Figure 3). These findings were consistent with metastatic MCC. Further culture revealed colonization with Scopulariopsis species for which he was started on Posaconazole. He was started on palliative radiation therapy and he declined chemotherapy. Repeat MRI in 1 month and

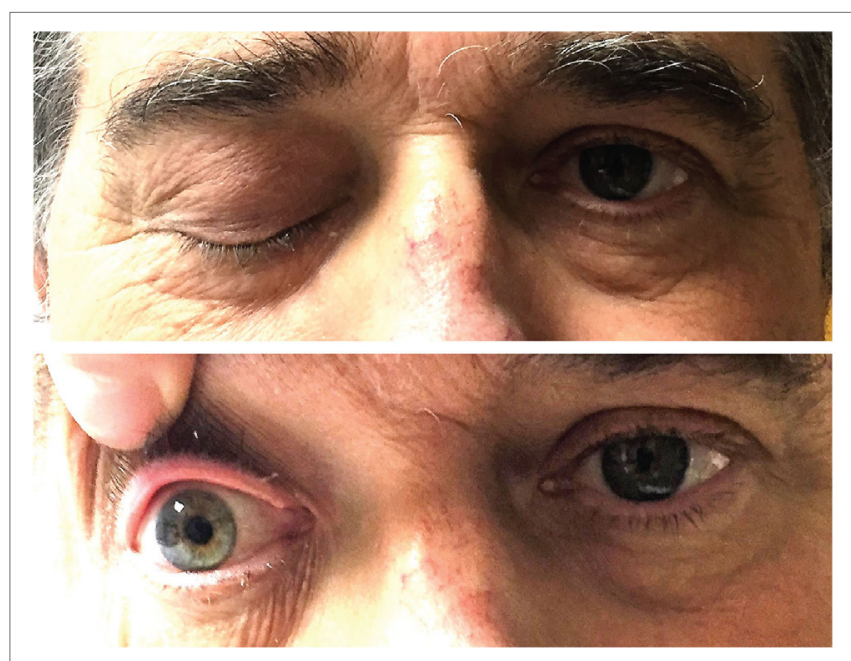

FIGURE 1 | Ptosis of the right eye and fixed and dilated right pupil.
CT scan 2 months later did not reveal progression of the clival metastasis, but new metastatic lesions were found in the cervical spine involving C2, C3, C5, and C6 vertebral bodies. He was put on a cervical collar, but no further surgical or radiation therapy was performed as the patient was asymptomatic. Hospice was considered but the patient declined due to the need to stop his antirejection medications. At the time of submission of this manuscript, 6 months after the initial discovery of the Merkel cell metastasis to the clivus, the patient remained alive.

\section{BACKGROUND}

Merkel cell carcinoma is a rare but aggressive cutaneous neuroendocrine tumor. Our case is unique in that the patient presented with right III, IV, V1, VI and left V3, VI cranial nerve palsies without proptosis, mimicking Tolosa-Hunt syndrome or bilateral cavernous sinus thrombosis. This is the first case showing distant MCC metastasis to the clivus with invasion of the cavernous sinuses. His presentation with complete right ptosis, fixed and dilated pupil along with impairment of all extraocular movement of the right eye is unique. The only case report of metastatic MCC involving the cavernous sinus was by Chang et al. (1). However, that case presented only with retro-orbital pain and hemifacial, hemi-tongue numbness. In addition, the primary site of the MCC was on the face 2 years prior to his presentation, with subsequent perineural spread to the brain and leptomeningeal dissemination.

Clivus is a part of the cranium at the skull base sitting adjacent to the sphenoid sinuses and cavernous sinuses. The abducens nerves tracks along the clivus and a tumor within the clival space can often cause abducens nerve palsies (2). This patient presented with bilateral abducens nerve palsy, which is compatible with the clival metastasis. The infiltration into the cavernous sinuses caused right CN III, IV, V1. The left V3 nerve can be secondary to the clival mass or to extension of the cavernous sinus tumor infiltration since V3 is located adjacent to both structures (Figure 2D).

Merkel cell carcinoma brain metastases typically occur after a mean period of 19.7 months (3). The patient presented here was diagnosed and treated for MCC just 4 months prior to his presentation. The growth of his MCC metastasis was also rapid. Brain MRI with contrast 3 months prior to his ocular symptoms did not show any sign of metastasis. He progressed rapidly within 3 weeks of symptom onset and his clinical picture was not concerning enough for an ophthalmologist who examined him 2 weeks prior to his presentation.

Our literature review revealed a total of 40 cases of MCC metastasis to the central nervous system (Table 1). The average age at the time of metastasis is 63.66 years old with $60 \%$ of the cases being male. $97 \%$ of the cases ( 39 out of 40 cases) had metastasis to the brain or leptomeninges, with the only exception being the report by Chang et al. with perineural spread to the bilateral acoustic meatus and trigeminal cistern (1). The average time for CNS spread after the primary diagnosis is 24.77 months. The survival rate after the CNS diagnosis is $73 \%$ at 6 months and $33 \%$ at 1 year. This is consistent with the previous report of a median survival time of 8.5 months after a diagnosis of Merkel cell 

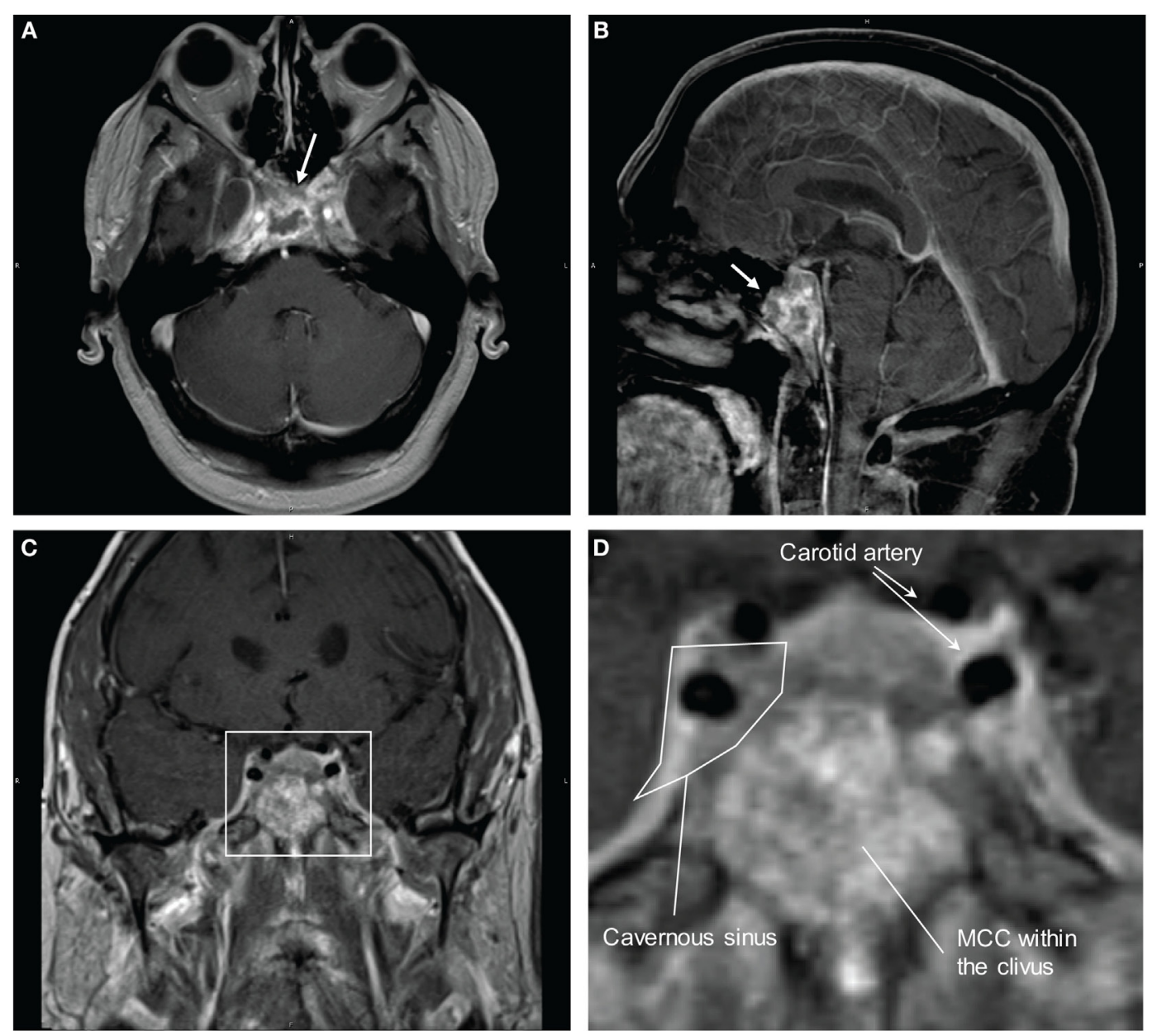

FIGURE 2 | MRI brain with contrast showing Merkel cell carcinoma (MCC) metastasis to the clivus and invasion into the cavernous sinus. (A) Transverse view. Arrow is pointing to the mass in the clivus. (B) Sagittal view. Arrow is pointing to the mass in the clivus. (C) Coronal view. (D) Magnified view of the cavernous sinus from (C). There is invasion of the metastatic MCC into the cavernous sinus with likely impingement on the cranial nerves.
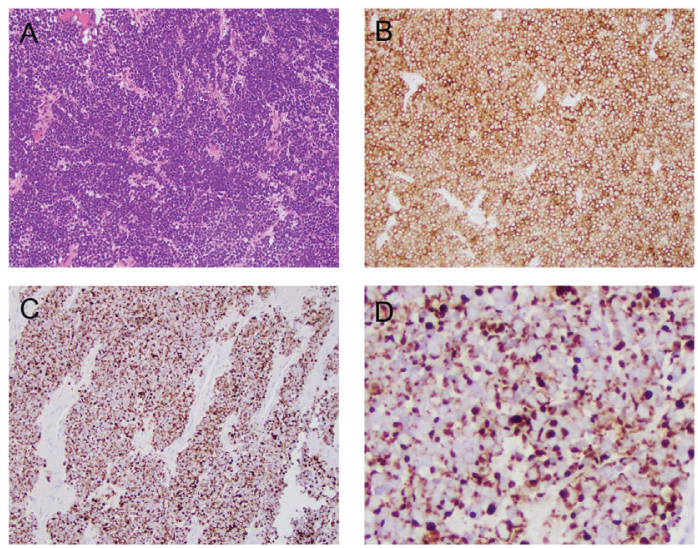

FIGURE 3 | Histological and immunophenotypical features of the clival mass. (A) H\&E stain at 20x showing small round blue cells. (B) CD56 stain positive. (C) Cytokeratin CAM 5.2 stain positive. (D) Magnified view of the cytokeratin CAM 5.2 stain showing perinuclear dot-like pattern.
CNS metastasis (4). None of the reported cases described prior immunosuppression before MCC was detected. The reported case here was diagnosed at age of 60,4 months after the diagnosis of the primary tumor. He had multiple comorbidities including multiorgan transplant status which, along with metastatic MCC, indicate a poor prognosis.

\section{DISCUSSION}

When the patient first presented, Tolosa-Hunt syndrome and cavernous sinus thrombosis were the top two differential diagnoses. However, cavernous sinus thrombosis typically presents with proptosis (80-100\%) (31), and our patient did not, making Tolosa-Hunt syndrome a more compelling etiology on presentation. Tolosa-Hunt syndrome is an idiopathic, sterile inflammation affecting the cavernous sinus. It is defined by the International Headache Society as "episodic orbital pain associated with paralysis of one or more of the third, fourth, and/or sixth cranial nerves, which usually resolves spontaneously 
TABLE 1 | Literature review of central nervous system metastasis of Merkel cell carcinoma.

\begin{tabular}{|c|c|c|c|c|c|c|}
\hline Case & Age/sex & Primary lesion & Location of metastasis & $\begin{array}{l}\text { Time to CNS } \\
\text { disease after } \\
\text { primary Dx }\end{array}$ & $\begin{array}{l}\text { Survival } \\
\text { after CNS } \\
\text { metastasis }\end{array}$ & $\begin{array}{l}\text { Immunosuppression } \\
\text { before primary } \\
\text { lesion }\end{array}$ \\
\hline Kroll et al. (5) & $48 \mathrm{M}$ & NA & Brain & NA & NA & None \\
\hline Kroll et al. (5) & $70 M$ & NA & Brain & NA & NA & None \\
\hline Kroll et al. (5) & $72 \mathrm{~F}$ & NA & Meninges & NA & NA & None \\
\hline Wick et al. (6) & $62 \mathrm{M}$ & Face & Brain & 12 months & 1 month & None \\
\hline Wick et al. (6) & $76 \mathrm{M}$ & $\begin{array}{l}\text { Right retroauricular } \\
\text { area }\end{array}$ & Brain & 3 years & 0 month & None \\
\hline Goepfert et al. (7) & NA & NA & Brain & NA & NA & None \\
\hline Giannone et al. (8) & $57 \mathrm{~F}$ & Scalp & Right frontoparietal & 2 months & $\begin{array}{l}4 \text { months, } \\
\text { survived }\end{array}$ & None \\
\hline Grosh et al. (9) & $57 \mathrm{~F}$ & NA & Brain & 2 months & 12 months & None \\
\hline Grosh et al. (9) & $56 \mathrm{M}$ & NA & Brain & $\geq 21$ months & NA & None \\
\hline Hitchcock et al. (10) & $52 \mathrm{M}$ & Left breast & Brain & 3 months & 9 months & None \\
\hline Knox et al. (11) & $75 \mathrm{~F}$ & Right neck & Left cerebellum & 4 years & NA & None \\
\hline Knox et al. (11) & $60 \mathrm{M}$ & Inguinal nodes & Leptomeninges & 10 months & 14 months & None \\
\hline Dudley et al. (12) & $64 \mathrm{M}$ & NA & Leptomeninges & 17 months & 6 days & None \\
\hline Alexander et al. (13) & $56 \mathrm{M}$ & Left face & Right parietal & Present at $d x$ & 3 years & None \\
\hline Wojak and Murali (14) & $78 \mathrm{~F}$ & NA & Calvaria, Dura & Present at $\mathrm{dx}$ & $\geq 1$ year & None \\
\hline Manome et al. (15) & $57 \mathrm{~F}$ & NA & Frontal skull base, brain & Present at $d x$ & NA & None \\
\hline Small et al. (16) & $56 \mathrm{M}$ & NA & Brain & Present at $d x$ & 22 months & None \\
\hline Yiengpruksawan et al. (17) & NA & NA & Brain & NA & NA & None \\
\hline Sharma et al. (18) & $57 \mathrm{M}$ & & Brain & Present at $\mathrm{dx}$ & 13 months & None \\
\hline Snodgrass et al. (19) & $61 \mathrm{M}$ & Forehead & Right parietal, leptomeninges & 1 year & 6 months & None \\
\hline Eftekhari et al. (20) & NA & NA & Brain & NA & NA & None \\
\hline Eftekhari et al. (20) & NA & NA & Brain & NA & NA & None \\
\hline Eftekhari et al. (20) & NA & NA & Brain & NA & NA & None \\
\hline Matula et al. (21) & $47 \mathrm{M}$ & NA & Anterior skull base, dura, brain & Present at $d x$ & 12 months & None \\
\hline Straka et al. (22) & $71 \mathrm{~F}$ & NA & Brain & 10 months & 2 months & None \\
\hline Litofsky et al. (23) & $86 F$ & $\begin{array}{l}\text { External auditory } \\
\text { canal }\end{array}$ & Brain & 16 months & $\geq 8$ months & None \\
\hline Ikawa et al. (24) & $48 \mathrm{~F}$ & Left elbow & Right cerebellum & 5 years & 11 months & None \\
\hline Eggers et al. (25) & $69 M$ & NA & Pons and midbrain, leptomeninges & 17 months & $<2$ months & None \\
\hline Barkdull et al. (26) & $55 \mathrm{M}$ & Scalp & Calvaria, Dura & Present at $d x$ & 10 months & None \\
\hline Faye et al. (27) & $85 \mathrm{M}$ & NA & Right parietal & 1 year & NA & None \\
\hline Faye et al. (27) & $68 \mathrm{M}$ & NA & Brain, leptomeninges & 1 year & 7 months & None \\
\hline Chang et al. (1) & $45 \mathrm{M}$ & Left temporal skin & $\begin{array}{l}\text { Bilateral internal acoustic } \\
\text { meatus, left trigeminal cistern }\end{array}$ & 2 years & $\geq 3$ months & None \\
\hline De Cicco et al. (28) & $69 \mathrm{M}$ & NA & Brain & 22 months & 6 months & None \\
\hline Feletti et al. (3) & $65 F$ & NA & Pituitary & 3.5 years & $\geq 8$ months & None \\
\hline Bailey et al. (4) & $75 F$ & Nasal ala & Right parietal & 1 year & $\overline{7}$ months & None \\
\hline Bailey et al. (4) & $77 \mathrm{~F}$ & Left scalp & Parietal lobe, scalp & Present at $d x$ & $\geq 16$ months & None \\
\hline Bailey et al. (4) & $51 \mathrm{~F}$ & $\begin{array}{l}\text { Right calf/inguinal } \\
\text { lymph nodes }\end{array}$ & Right temporal lobe & 4 years & $\begin{array}{l}>21 \text { months, } \\
\text { survived }\end{array}$ & None \\
\hline Abul-Kasim et al. (29) & $65 \mathrm{M}$ & $\begin{array}{l}\text { Left inguinal, iliac, } \\
\text { aortocaval lymph } \\
\text { nodes }\end{array}$ & Right parietal, lumbar spine & NA & $\begin{array}{l}8 \text { months, } \\
\text { survived }\end{array}$ & None \\
\hline Seaman et al. (30) & $78 \mathrm{M}$ & Right groin & $\begin{array}{l}\text { Left central pontine angle } \\
\text { mass }\end{array}$ & 2 months & $\begin{array}{l}5 \text { months, } \\
\text { survived }\end{array}$ & None \\
\hline This report & $60 \mathrm{M}$ & Left shoulder & Clivus, cavernous sinus & 4 months & - & Yes \\
\hline Average & $\begin{array}{l}63.66 \text { years } \\
\text { old } \\
60 \% \mathrm{M}\end{array}$ & - & - & $24.76 \pm 19.5$ months & $\begin{array}{l}6 \text { months } \\
\text { survival: } 73 \% \\
12 \text { months } \\
\text { survival: 33\% }\end{array}$ & \\
\hline
\end{tabular}

but tends to relapse and remit" (32). Tolosa-Hunt syndrome is typically unilateral, with bilateral symptoms occurring in only about $4 \%$ of the cases (33). Cranial nerve III is the most commonly affected cranial nerve $(78.3 \%)$, followed by cranial nerve VI (41.3\%), cranial nerve IV (30.4\%), the ophthalmic branch of cranial nerve V (28.1\%), and cranial nerve II (10.9\%). Multiple nerves may be affected simultaneously in $54.3 \%$ of patients (33). The maxillary and mandibular divisions of the fifth nerve and even facial nerve may be affected $(34,35)$. Abnormal MRI findings occurr in only $52 \%$ of the patients (33). The patient presented here had involvement of the right cranial nerve III, IV, VI, and ophthalmic branch of V, as well as left cranial nerve VI and mandibular division of V. There was orbital pain behind the right eye. Other than the prolonged duration 
(3 weeks), the clinical picture would fit Tolosa-Hunt syndrome. MCC metastasis did not become the top differential diagnosis until MRI brain was obtained.

The patient was immunocompromised due to the use of immunosuppressants for his renal and pancreatic transplants. Immunosuppression is a significant risk factor, as the risk of developing MCC significantly increases with human immunodeficiency virus $(36,37)$, and chronic lymphocytic leukemia $(38,39)$. Solid organ transplant status has also been shown to increase the risk of developing MCC by 23.8-fold (40). In the study by Clarke et al., the incidence of MCC in renal transplant was 13.8 per 100,000 person-year, which translates to 25.7 -fold increase in risk of developing MCC compared to the general population. In another study, the standardized incidence ratio of MCC is as high as 66 for patients with renal transplant (41). In that study, three cases of MCC were detected among 4,200 individuals who underwent renal transplantation. All three identified cases were on immunosuppressive medications. The latency between transplant and MCC ranged from 6 to 19 years. All three cases died and the survival time between diagnosis of MCC and death ranged from 0.5 to 2.1 years. Our patient had both renal and pancreatic transplant, which likely increased his risk of developing MCC. He developed MCC 8 years after his renal and pancreatic transplant, which is in line with the reported latency.

Merkel cell polyoma virus was detected in about $80 \%$ of all MCCs (42). Because immunosuppression has been shown to be a significant risk factor, it has been hypothesized that immunosuppression after an organ transplant increases the risk of Merkel cell polyoma virus infection and thus increases the risk of developing MCC. However, the study by Koljonen et al. (41) showed that only one out of the three MCC cases with renal transplant status (33\%) was tested positive for Merkel cell polyoma virus. This rate was lower than the $80 \%$ expected in the general population. Even though these data argue against the hypothesis of polyoma virus being the underlying cause of MCC

\section{REFERENCES}

1. Chang DT, Mancuso AA, Riggs CE, Mendenhall WM. Merkel cell carcinoma of the skin with leptomeningeal metastases. Am J Otolaryngol (2005) 26:210-3. doi:10.1016/j.amjoto.2004.11.013

2. Pallini R, Sabatino G, Doglietto F, Lauretti L, Fernandez E, Maira G. Clivus metastases: report of seven patients and literature review. Acta Neurochir (Wien) (2009) 151:291-6; discussion 296. doi:10.1007/s00701009-0229-1

3. Feletti A, Marton E, Rossi S, Canal F, Longatti P, Billeci D. Pituitary metastasis of Merkel cell carcinoma. J Neurooncol (2010) 97:295-9. doi:10.1007/ s11060-009-0025-Z

4. Bailey TL, Fung MA, Gandour-Edwards R, Ellis WG, Schrot RJ. Clinical emergence of neurometastatic merkel cell carcinoma: a surgical case series and literature review. J Neurooncol (2011) 102:147-55. doi:10.1007/ s11060-010-0304-8

5. Kroll MH, Toker C. Trabecular carcinoma of the skin: further clinicopathologic and morphologic study. Arch Pathol Lab Med (1982) 106: 404-8.

6. Wick MR, Goellner JR, Scheithauer BW, Thomas JR, Sanchez NP, Schroeter AL. Primary neuroendocrine carcinomas of the skin (Merkel cell tumors). A clinical, histologic, and ultrastructural study of thirteen cases. Am J Clin Pathol (1983) 79:6-13. doi:10.1093/ajcp/79.1.6 in organ transplant patients, the sample size is currently too small to draw a conclusion. Unfortunately, in the case presented here, we do not have the Merkel cell polyoma virus data available.

\section{CONCLUDING REMARKS}

This case is unique because it is the only case report showing MCC metastasis to the clivus from a distant site. It also demonstrates that MCC metastasis symptoms can progress rapidly within weeks and can masquerade as symptoms of Tolosa-Hunt syndrome or cavernous sinus thrombosis.

\section{ETHICS STATEMENT}

Retrospective case report (exempted). Informed consent was signed for publication. Patient was not identified.

\section{AUTHOR CONTRIBUTIONS}

$\mathrm{KH}$ drafted the manuscript and compiled the figures, tables, and videos. PD provided pathological images and reviewed the manuscript. MC designed and supervised the work and critically reviewed the manuscript.

\section{FUNDING}

Publication of this article was funded in part by the University of Florida Open Access Publishing Fund.

\section{SUPPLEMENTARY MATERIAL}

The Supplementary Material for this article can be found online at http://journal.frontiersin.org/article/10.3389/fneur.2017.00409/ full\#supplementary-material.

VIDEO S1 | Extraocular movements of the patient.

7. Goepfert H, Remmler D, Silva E, Wheeler B. Merkel cell carcinoma (endocrine carcinoma of the skin) of the head and neck. Arch Otolaryngol (1984) 110:707-12. doi:10.1001/archotol.1984.00800370009002

8. Giannone L, Johnson DH, Grosh WW, Davis BW, Marangos PJ, Greco FA. Serum neuron-specific enolase in metastatic Merkel cell tumors. Med Pediatr Oncol (1985) 13:357-62. doi:10.1002/mpo.2950130611

9. Grosh WW, Giannone L, Hande KR, Johnson DH. Disseminated Merkel cell tumor. Treatment with systemic chemotherapy. Am J Clin Oncol (1987) 10:227-30. doi:10.1097/00000421-198706000-00011

10. Hitchcock CL, Bland KI, Laney RG, Franzini D, Harris B, Copeland EM. Neuroendocrine (Merkel cell) carcinoma of the skin. Its natural history, diagnosis, and treatment. Ann Surg (1988) 207:201-7. doi:10.1097/ 00000658-198802000-00015

11. Knox SJ, Kapp DS. Hyperthermia and radiation therapy in the treatment of recurrent Merkel cell tumors. Cancer (1988) 62:1479-86. doi:10.1002/10970142(19881015)62:8<1479::AID-CNCR2820620806>3.0.CO;2-H

12. Dudley TH, Moinuddin S. Cytologic and immunohistochemical diagnosis of neuroendocrine (Merkel cell) carcinoma in cerebrospinal fluid. Am J Clin Pathol (1989) 91:714-7. doi:10.1093/ajcp/91.6.714

13. Alexander E, Rossitch E, Small K, Rosenwasser GO, Abson P. Merkel cell carcinoma. Long term survival in a patient with proven brain metastasis and presumed choroid metastasis. Clin Neurol Neurosurg (1989) 91:317-20. doi:10.1016/0303-8467(89)90007-3 
14. Wojak JC, Murali R. Primary neuroendocrine (Merkel cell) carcinoma presenting in the calvarium: case report. Neurosurgery (1990) 26:137-9. doi:10.1227/00006123-199001000-00021

15. Manome Y, Yamaoka R, Yuhki K, Hano H, Kitajima T, Ikeuchi S. [Intracranial invasion of neuroendocrine carcinoma: a case report]. No Shinkei Geka (1990) 18:483-7.

16. Small KW, Rosenwasser GO, Alexander E, Rossitch G, Dutton JJ. Presumed choroidal metastasis of Merkel cell carcinoma. Ann Ophthalmol (1990) 22:187-90.

17. Yiengpruksawan A, Coit DG, Thaler HT, Urmacher C, Knapper WK. Merkel cell carcinoma. Prognosis and management. Arch Surg (1991) 126:1514-9. doi:10.1001/archsurg.1991.01410360088014

18. Sharma D, Flora G, Grunberg SM. Chemotherapy of metastatic Merkel cell carcinoma: case report and review of the literature. Am J Clin Oncol (1991) 14:166-9. doi:10.1097/00000421-199104000-00014

19. Snodgrass SM, Landy H, Markoe AM, Feun L. Neurologic complications of Merkel cell carcinoma. JNeurooncol (1994) 22:231-4. doi:10.1007/ BF01052924

20. Eftekhari F, Wallace S, Silva EG, Lenzi R. Merkel cell carcinoma of the skin: imaging and clinical features in 93 cases. Br J Radiol (1996) 69:226-33. doi:10.1259/0007-1285-69-819-226

21. Matula C, Roessler K, Burian M, Schuster H, Trattnig S, Hainfellner JA, et al. Primary neuroendocrine (Merkel cell) carcinoma of the anterior skull base. Skull Base Surg (1997) 7:151-8. doi:10.1055/s-2008-1058607

22. Straka JA, Straka MB. A review of Merkel cell carcinoma with emphasis on lymph node disease in the absence of a primary site. Am J Otolaryngol (1997) 18:55-65. doi:10.1016/S0196-0709(97)90050-8

23. Litofsky NS, Smith TW, Megerian CA. Merkel cell carcinoma of the external auditory canal invading the intracranial compartment. Am J Otolaryngol (1998) 19:330-4. doi:10.1016/S0196-0709(98)90008-4

24. Ikawa F, Kiya K, Uozumi T, Yuki K, Takeshita S, Hamasaki O, et al. Brain metastasis of Merkel cell carcinoma. Case report and review of the literature. Neurosurg Rev (1999) 22:54-7. doi:10.1007/s101430050010

25. Eggers SD, Salomao DR, Dinapoli RP, Vernino S. Paraneoplastic and metastatic neurologic complications of Merkel cell carcinoma. Mayo Clin Proc (2001) 76:327-30. doi:10.4065/76.3.327

26. Barkdull GC, Healy JF, Weisman RA. Intracranial spread of Merkel cell carcinoma through intact skull. Ann Otol Rhinol Laryngol (2004) 113:683-7. doi:10.1177/000348940411300901

27. Faye N, Lafitte F, Martin Duverneuil N, Guillevin R, Teriitehau C, Cordoliani YS, et al. Merkel cell tumor: report of two cases and review of the literature. J Neuroradiol (2005) 32:138-41. doi:10.1016/S0150-9861(05)83129-3

28. De Cicco L, Vavassori A, Jereczek-Fossa BA, Pruneri G, Catalano G, Ferrari AM, et al. Lymph node metastases of Merkel cell carcinoma from unknown primary site: report of three cases. Tumori (2008) 94:758-61.

29. Abul-Kasim K, Söderström K, Hallsten L. Extensive central nervous system involvement in Merkel cell carcinoma: a case report and review of the literature. J Med Case Rep (2011) 5:35. doi:10.1186/1752-1947-5-35

30. Seaman B, Brem S, Fromm A, Staller A, McCardle T, Jain S. Intracranial spread of Merkel cell carcinoma to the cerebellopontine angle. J Cutan Med Surg (2012) 16:54-60. doi:10.1177/120347541201600111
31. Ebright JR, Pace MT, Niazi AF. Septic thrombosis of the cavernous sinuses Arch Intern Med (2001) 161:2671-6. doi:10.1001/archinte.161.22.2671

32. Headache Classification Committee of the International Headache Society (IHS). The international classification of headache disorders, 3rd edition (beta version). Cephalalgia (2013) 33:629-808. doi:10.1177/ 0333102413485658

33. Zhang X, Zhou Z, Steiner TJ, Zhang W, Liu R, Dong Z, et al. Validation of ICHD-3 beta diagnostic criteria for 13.7 Tolosa-Hunt syndrome: analysis of 77 cases of painful ophthalmoplegia. Cephalalgia (2014) 34:624-32. doi: $10.1177 / 0333102413520082$

34. Tessitore E, Tessitore A. Tolosa-Hunt syndrome preceded by facial palsy. Headache (2000) 40:393-6. doi:10.1046/j.1526-4610.2000.00060.x

35. Inzitari D, Sità D, Marconi GP, Barontini F. The Tolosa-Hunt syndrome: further clinical and pathogenetic considerations based on the study of eight cases. J Neurol (1981) 224:221-8. doi:10.1007/BF00313284

36. An KP, Ratner D. Merkel cell carcinoma in the setting of HIV infection. J Am Acad Dermatol (2001) 45:309-12. doi:10.1067/mjd.2001.114732

37. Engels EA, Frisch M, Goedert JJ, Biggar RJ, Miller RW. Merkel cell carcinoma and HIV infection. Lancet (2002) 359:497-8. doi:10.1016/ S0140-6736(02)07668-7

38. Kaae J, Hansen AV, Biggar RJ, Boyd HA, Moore PS, Wohlfahrt J, et al. Merkel cell carcinoma: incidence, mortality, and risk of other cancers. J Natl Cancer Inst (2010) 102:793-801. doi:10.1093/jnci/djq120

39. Howard RA, Dores GM, Curtis RE, Anderson WF, Travis LB. Merkel cell carcinoma and multiple primary cancers. Cancer Epidemiol Biomarkers Prev (2006) 15:1545-9. doi:10.1158/1055-9965.EPI-05-0895

40. Clarke CA, Robbins HA, Tatalovich Z, Lynch CF, Pawlish KS, Finch JL, et al. Risk of Merkel cell carcinoma after solid organ transplantation. J Natl Cancer Inst (2015) 107:dju382. doi:10.1093/jnci/dju382

41. Koljonen V, Kukko H, Tukiainen E, Böhling T, Sankila R, Pukkala E, et al. Incidence of Merkel cell carcinoma in renal transplant recipients. Nephrol Dial Transplant (2009) 24:3231-5. doi:10.1093/ndt/gfp334

42. Feng H, Shuda M, Chang Y, Moore PS. Clonal integration of a polyomavirus in human Merkel cell carcinoma. Science (2008) 319:1096-100. doi:10.1126/ science. 1152586

Conflict of Interest Statement: The authors declare that the research was conducted in the absence of any commercial or financial relationships that could be construed as a potential conflict of interest.

The reviewer, AT, and handling editor declared their shared affiliation and the handling editor states that the process nevertheless met the standards of a fair and objective review.

Copyright (C) 2017 Ho, Drew and Chuquilin. This is an open-access article distributed under the terms of the Creative Commons Attribution License (CC BY). The use, distribution or reproduction in other forums is permitted, provided the original author(s) or licensor are credited and that the original publication in this journal is cited, in accordance with accepted academic practice. No use, distribution or reproduction is permitted which does not comply with these terms. 